\title{
PENGARUH TEKANAN KETAATAN, KOMPLEKSITAS TUGAS, PENGALAMAN, DAN MOTIVASI TERHADAP AUDIT JUDGMENT, GENDER SEBAGAI VARIABEL MODERATING
}

\author{
Noor Janah \\ Arif Sapta Yuniarto
}

\section{ABSTRACT}

This research has a purpose to understand and to analyze the influence of obedient pressure, task complexity, experience, and motivation for audit judgment with gender as moderating variable. From this research, it is able to get empirical evidence about the influence of obedient pressure, task complexity, experience, and motivation for audit judgment. Besides, this research also gives empirical evidence about the difference between man and woman in deciding audit judgment whether it correlates with several factor such as obedient pressure, task complexity, experience, and motivation. In this research, the researcher uses sample for auditors which is serve in the Public Accountant Office in DIY and Semarang. In this research, primary data is used as data, while General Linear Model (GLM) with helping IBM SPSS version 19.0 is used as analysis instrument. The result of this research is to indicate that task complexity influence for audit judgment, while obedient pressure, experience, and motivation do not influence for audit judgment. The issue about gender difference do not also moderate the influence of obedient pressure, task complexity, experience, and motivation for audit judgment.

Keywords: gender, obedient pressure, task complexity, experience, and motivation, audit judgment.

\section{PENDAHULUAN}

Akuntan adalah suatu profesi yang salah satu tugasnya adalah melaksanakan audit terhadap laporan keuangan sebuah entitas dan memberikan opini atau pendapat terhadap saldo akun dalam laporan keuangan apakah telah disajikan secara wajar sesuai dengan standar akuntansi keuangan atau prinsip akuntansi yang berlaku umum; dan standar atau prinsip tersebut diterapkan secara konsisten. Pelaksanakan tugas tersebut sering dibutuhkan judgment (Zulaikha, 2006).

Akan tetapi dalam melaksanakan penugasan audit, ada beberapa faktor yang mempengaruhi persepsi auditor dalam menanggapi dan mengevaluasi informasi ini antara lain meliputi faktor pengetahuan, pengalaman, perilaku auditor dalam memperoleh dan mengevaluasi informasi, tekanan dari atasan ataupun klien, kompleksitas tugas dalam melakukan pemeriksaan, serta motivasi seorang auditor 
sendiri. Gender diduga menjadi salah satu faktor level individu yang turut mempengaruhi kualitas audit judgment seiring dengan terjadinya perubahan pada kompleksitas tugas, pengaruh tingkat kepatuhan terhadap etika, pengalaman, serta motivasi dalam diri seseorang. Secara umum, pengertian gender adalah perbedaan yang tampak antara laki-laki dan perempuan apabila dilihat dari segi pengaruh sosial budaya, khususnya jika dilihat dari nilai, peran, mentalitas, karakteristik emosional, dan tingkah laku.

Perbedaan gender sebenarnya tidak menjadi masalah sepanjang tidak melahirkan ketidakadilan gender. Namun pada sebagian besar organisasi, perbedaan gender masih mempengaruhi kesempatan dan kekuasaan. Literatur Chung and Monroe (2001) dalam Zulaikha (2006) menyatakan bahwa perempuan dapat lebih efisien dan efektif dalam memproses informasi dalam tugas yang kompleks dibanding laki-laki. Pengaruh gender terhadap pemrosesan informasi dan judgment belum banyak teruji dalam konteks penugasan audit atau penugasan sebagai auditor.

Menurut Mangkunegara (2005: 29), tekanan ketaatan adalah suatu kondisi ketegangan yang menciptakan adanya ketidakseimbangan fisik dan psikis, yang mempengaruhi emosi, proses berpikir dan kondisi seorang karyawan, dalam hal ini tekanan tersebut disebabkan oleh lingkungan pekerjaan tempatnya bekerja. Terdapat dua macam tekanan ketaatan, yaitu perintah dari atasan dan keinginan klien untuk menyimpang dari standar profesional auditor.

Teori ketaatan menyatakan bahwa individu yang memiliki kekuasaan merupakan suatu sumber yang dapat mempengaruhi orang lain dengan perintah yang diberikannya. Hal ini disebabkan oleh keberadaan kekuasaan atau otoritas yang merupakan bentuk dari legitimate power. Tekanan ketaatan memberikan pengaruh terhadap audit judgment terkait dengan tekanan pada saat pelaksanaan tugas, kode etik, pertimbangan-pertimbangan, dan konflik-konflik yang mendasari pertimbangan-pertimbangan itu. Reugger and King (1992) dalam Jamilah, dkk (2007) menyatakan perempuan umumnya memiliki tingkat pertimbangan moral yang lebih tinggi dari pada laki-laki. Temuan DeZoort and Lord dalam Hartanto (2001) melihat adanya pengaruh tekanan atasan pada judgment yang diambil 
auditor. Gilligan (1982) dalam Jamilah (2007) menyatakan bahwa pengaruh gender terhadap perbedaan persepsi etika terjadi pada saat proses pengambilan keputusan.

Selain tekanan ketaatan, terdapat beberapa faktor yang berpengaruh terhadap kinerja seorang auditor dalam mengambil keputusan, salah satunya adalah meningkatnya kompleksitas tugas yang dihadapi. Kompleksitas tugas merupakan tugas yang tidak terstruktur, membingungkan, dan sulit (Sanusi dan Iskandar, 2007 dalam Irwanti, 2011). Pengalaman merupakan imbalan sekaligus sebagai faktor pendorong perkembangan keterampilan seseorang. Meskipun tidak ada aktivitas tunggal yang dapat mengubah seseorang menjadi pandai, beberapa pengalaman tertentu dapat memberikan kontribusi pada kemampuan seseorang. Puspa (2006) dalam Susetyo (2009) mengatakan bahwa auditor dengan tingkat pengalaman yang hampir sama (memiliki masa kerja dan penugasan yang hampir sama) ternyata memiliki pertimbangan yang berbeda-beda dan sangat bervariasi.

Uang bukanlah satu-satunya hal yang mampu memotivasi seorang auditor dalam menentukan judgment-nya karena sebagian auditor melihat bahwa uang bukanlah motivator yang sifatnya berkelanjutan. Walaupun kurang tepat mengabaikan kekuatan uang sebagai motivator. Sebab, banyak orang melihat pekerjaan sebagai sesuatu yang memberikan kepada mereka kesempatan untuk belajar, dan juga kesempatan untuk membuat keputusan (Tyson \& Tony, 1992: 32). Setiap orang memiliki banyak kebutuhan dan kebutuhan setiap orang berbeda-beda, beberapa di antaranya adalah kebutuhan untuk berprestasi, kekuasaan, otonomi, dan afiliasi.

Penelitian yang dilakukan oleh Jamilah, dkk (2007) yang juga membahas tentang gender, kompleksitas tugas, serta tekanan ketaatan kaitannya dengan audit judgment, memberikan hasil penelitian yang konsisten dengan penelitian yang dilakukan oleh Zulaikha (2006) yang menyatakan bahwa gender dan kompleksitas tugas tidak berpengaruh terhadap audit judgment. Berdasar latar belakang masalah, maka peneliti tertarik untuk meneliti mengenai pengaruh tekanan ketaatan, kompleksitas tugas, pengalaman, dan motivasi terhadap audit judgment, dengan gender sebagai variabel pemoderasi. 


\section{KAJIAN TEORITIS DAN PENGEMBANGAN HIPOTESIS}

\section{Pengaruh Tekanan Ketaatan terhadap Judgment yang Diambil oleh Auditor}

Hampir semua penalaran dan pengambilan keputusan terjadi dengan adanya sedikit ketidakpastian (King, 2010: 233). Seorang auditor dapat memberikan judgment yang berbeda dengan hasil temuannya jika auditor tersebut memperoleh tekanan baik itu dari atasan maupun dari klien. Penelitian yang dilakukan oleh Hartanto dan Indra (2001) menyebutkan bahwa tekanan ketaatan dari atasan berpengaruh secara signifikan terhadap judgment yang diambil oleh auditor. Tidak menutup kemungkinan apabila seorang auditor mendapat perintah yang kurang tepat langsung dari atasan ataupun klien, maka auditor tersebut tetap melaksanakan tugasnya walaupun sebenarnya perintah tersebut bertentangan dengan kepribadian dan kemauannya. Hal tersebut bisa terjadi karena auditor sadar akan adanya konsekuensi yang jelas dari sikap ketidaktaatan. Namun pertimbangan moral dan profesionalisme memainkan peran penting dalam pengambilan keputusan akhir. Berdasar hal tersebut, hipotesis yang dapat dirumuskan adalah:

$\mathrm{H}_{1}$ : Tekanan ketaatan berpengaruh terhadap judgment yang diambil oleh auditor.

\section{Pengaruh Kompleksitas Tugas terhadap Judgment yang Diambil oleh Auditor}

Tugas audit merupakan sebuah tugas yang banyak menghadapi persoalan yang kompleks karena dalam melakukan tugas audit, auditor selalu dihadapkan dengan tugas yang banyak, berbeda-beda, saling terkait antara satu dengan yang lainnya, serta banyaknya konflik yang sering terjadi selama proses pengauditan berlangsung. Adanya peningkatan kompleksitas dalam suatu tugas, seorang karyawan, termasuk auditor dapat mengalami stres kerja. Kompleksitas audit dapat menyebabkan akuntan berperilaku disfungsional. Jika hal tersebut terjadi, maka kinerja pun akan menurun sehingga akan mempengaruhi judgment yang diambil oleh auditor. Hal ini sesuai dengan apa yang dikemukakan oleh Restuningdiah dan Indriantoro (1999) yang mengemukakan bahwa peningkatan kompleksitas dalam suatu tugas atau sistem, akan menurunkan tingkat keberhasilan tugas itu. Terkait dengan pengauditan, tingginya kompleksitas audit ini bisa menyebabkan akuntan berperilaku disfungsional sehingga menyebabkan penurunan kinerja auditor dalam 
pembuatan audit judgment. Berdasar hal tersebut, dapat dirumuskan hipotesis sebagai berikut:

$\mathrm{H}_{2}$ : Kompleksitas tugas mempengaruhi judgment yang diambil oleh auditor.

\section{Pengaruh Pengalaman terhadap Judgment yang Diambil oleh Auditor}

Pengalaman dapat membantu seseorang menggunakan strategi yang pernah digunakan serta kegagalan di masa lampau untuk melihat sebuah masalah dari sudut pandang yang berbeda. Pernyataan itu juga didukung oleh berbagai studi psikologi yang mengindikasikan bahwa familiaritas tugas mempunyai efek signifikan terhadap perilaku pengambilan risiko (risk-taking) pada individu di bawah ketidakpastian (Koroy, 2005). Hal ini sesuai dengan apa yang dikemukakan oleh Butts dalam Sularso dan Ainun (1999: 156), yang mengungkapkan bahwa akuntan pemeriksa yang berpengalaman membuat judgment lebih baik dalam tugastugas profesional ketimbang akuntan pemeriksa yang belum berpengalaman. Anderson dan Maletta (1994) dalam Koroy (2005) mengatakan bahwa auditor yang kurang berpengalaman terlalu terfokus pada informasi negatif sehingga semakin negatif juga mereka dalam membuat pertimbangan audit. Berdasarkan hal tersebut, maka dapat dirumuskan hipotesis sebagai berikut:

$\mathrm{H}_{3}$ : Pengalaman mempengaruhi judgment yang diambil oleh auditor.

\section{Pengaruh Motivasi terhadap Judgment yang Diambil oleh Auditor}

Motivasi merupakan penggerak dari dalam hati seseorang untuk melakukan atau mencapai suatu tujuan. Kaitannya dengan audit judgment, motivasi mampu mendorong seorang auditor untuk melakukan apa yang harus dia lakukan untuk mencapai tujuan dia melakukan audit, termasuk memberikan judgment-nya. Penelitian yang dilakukan oleh Suryanti (2010) menunjukkan bahwa motivasi kerja berpengaruh terhadap pengambilan keputusan oleh auditor. Berdasar uraian tersebut, maka dapat dirumuskan hipotesis sebagai berikut:

$\mathrm{H}_{4}$ : Motivasi berpengaruh terhadap judgment yang diambil oleh auditor. 


\section{Pengaruh Gender dalam Memoderasi Pengaruh Tekanan Ketaatan terhadap Judgment yang Diambil oleh Auditor}

Klien bisa menekan auditor dalam sebuah penugasan audit, untuk mengambil tindakan yang melanggar standar pemeriksaan sehingga klien dapat mempengaruhi proses pelaksanaan yang dilakukan oleh auditor. Seorang auditor yang memegang teguh etika profesi dan standar pemeriksaan akan berada dalam situasi konflik. Isu yang beredar akhir-akhir ini adalah kenyataan bahwa judgment yang diambil auditor laki-laki dan perempuan berbeda. Beberapa penelitian diperoleh bukti bahwa ada perbedaan judgment yang diambil antara auditor laki-laki dan perempuan ketika dihadapkan dengan etika. Brabeck (1987) dalam Hartanto dan Indra (2001) menemukan bahwa perempuan lebih sensitif pada isu-isu etik. Borkowski dan Urgas (1996) dalam Hartanto dan Indra (2001) berhasil menemukan adanya hubungan yang kuat dan konsisten antara pertimbangan moral dan gender, yang mengindikasikan bahwa perempuan memiliki pertimbangan moral yang lebih tinggi dibandingkan dengan laki-laki. Dengan demikian dapat dirumuskan hipotesis sebagai berikut:

$\mathrm{H}_{5}$ : Gender memoderasi pengaruh tekanan ketaatan terhadap audit judgment.

\section{Pengaruh Gender dalam Memoderasi Pengaruh Kompleksitas Tugas terhadap Judgment yang Diambil oleh Auditor.}

Tugas audit merupakan tugas yang kompleks, maka dari itu dibutuhkan ketelitian, keterampilan, dan kehati-hatian dalam pengambilan keputusan. Kaum laki-laki dalam mengolah informasi biasanya tidak menggunakan seluruh informasi yang tersedia sehingga keputusan yang diambil kurang komprehensif. Lain halnya dengan perempuan, mereka dalam mengolah informasi cenderung lebih teliti dengan menggunakan informasi yang lebih lengkap dan mengevaluasi kembali informasi tersebut serta tidak gampang menyerah (Meyer dan Levy, 1986 dalam Jamilah dkk, 2007). Kaum perempuan relatif lebih efisien dibandingkan kaum lakilaki selagi mereka mendapat akses informasi. Perempuan lebih tekun dan sanggup menyesuaikan diri pada situasi kerja keras yang terus menerus jika dibandingkan dengan laki-laki sehingga dapat mengalahkan laki-laki yang dipandang lebih cerdas jika dibanding dengan perempuan. Selain itu, hasil penelitian dari Giligan (1982), 
Sweeney dan Robert (1997), Barbeau dan Brabeck dalam Jamilah dkk (2007) juga mendukung argumen bahwa perempun lebih efisien dalam pengolahan informasi. Dengan demikian, hipotesis yang dirumuskan adalah sebagai berikut:

$\mathrm{H}_{6}$ : Gender memoderasi pengaruh kompleksitas tugas terhadap judgment yang diambil oleh auditor.

\section{Pengaruh Gender dalam Memoderasi Pengaruh Pengalaman Auditor terhadap Judgment yang Diambil oleh Auditor.}

Walaupun sama-sama seorang auditor, akan tetapi laki-laki dan perempuan kebanyakan mengalami hal yang berbeda dalam beberapa masalah. Terutama jika dihadapkan dengan kesempatan apabila dilihat dari segi nilai, peran, mentalitas, karakteristik emosional, dan tingkah laku. Sehingga dengan demikian berbeda pula cara mereka mengatasinya. Selain itu, adanya beberapa pendapat yang menyatakan bahwa memori perempuan lebih kuat jika dibandingkan dengan memori laki-laki, sehingga tidak menutup kemungkinan berbeda pula kualitas judgment yang dikeluarkan oleh auditor laki-laki dan perempuan. Penelitian sebelumnya, yaitu penelitian Zulaikha (2006) menemukan bahwa pengalaman auditor mempunyai main effect dan interaction effects dengan gender secara signifikan. Berdasar uraian tersebut, maka hipotesis yang dapat dirumuskan adalah:

$\mathrm{H}_{7}$ : Gender memoderasi pengaruh pengalaman auditor terhadap judgment yang diambil oleh auditor.

\section{Pengaruh Gender dalam Memoderasi Pengaruh Motivasi terhadap Judgment yang Diambil oleh Auditor.}

Motivasi intrinsik dapat berupa prestasi yang ingin dicapai, kepuasan akan hasil kerjanya, dan sebagainya. Sedangkan motivasi ekstrinsik dapat berupa status jabatan, uang, ingin dihargai, ataupun kompensasi lainnya. Perempuan cenderung memiliki motivasi intrinsik dibanding motivasi ekstrinsik (Liping, 2000 dalam Jardon et al., 2007). Banyak psikolog percaya bahwa motivasi intrinsik menghasilkan dampak yang lebih positif dibandingkan dengan motivasi ekstrinsik (Blumenfeld, Kempler, \& Kracjik, 2006; Brophy, 2004; Ryan \& Deci, 2001 dalam King, 2010: 90). Mereka berpendapat bahwa motivasi instrinsik lebih mungkin 
menghasilkan perilaku kompeten dan penguasaan. Berdasarkan uraian tersebut, maka dapat dirumuskan hipotesis sebagai berikut:

$\mathrm{H}_{8}$ : Gender memoderasi pengaruh motivasi terhadap judgment yang diambil oleh auditor.

\section{METODA PENELITIAN}

\section{Populasi dan Sampel}

Penelitian ini mengambil populasi auditor (junior, senior, supervisor, manajer, dan partner) yang bekerja di Kantor Akuntan Publik yang berada di wilayah DIY dan Semarang yang terdaftar pada direktori kantor akuntan publik yang dikeluarkan oleh Ikatan Akuntan Publik Indonesia (IAPI) tahun 2012. Teknik pengambilan sampel yang digunakan dalam penelitian ini adalah dengan menggunakan metoda purposive sampling. Adapun kriteria yang digunakan dalam pengembilan sampel ini adalah:

1. Auditor yang bekerja di kantor akuntan publik di wilayah DIY dan Semarang.

2. Auditor disemua level (junior, senior, supervisor, manajer, hingga partner).

Data yang digunakan dalam penelitian ini adalah data primer. Data primer diperoleh dengan menggunkan metoda survei yaitu melalui kuisioner. Kuisioner diantar langsung ke alamat kantor tempat auditor bekerja.

\section{Definisi Operasional Variabel}

Gender adalah suatu konsep yang digunakan untuk mengidentifikasi perbedaan laki-laki dan perempuan dilihat dari segi pengaruh sosial budaya maupun psikologis, khususnya jika dilihat dari nilai, peran, mentalitas, karakteristik emosional, dan tingkah laku. Gender merupakan variabel moderating yang dibedakan menjadi dua kategori yaitu laki-laki dan perempuan. Alat ukur yang digunakan merupakan alat ukur yang digunakan dalam penelitian Jamilah, dkk (2007).

Tekanan ketaatan merupakan tekanan yang diterima oleh auditor dalam menghadapi atasan dan klien untuk melakukan tindakan menyimpang dari standar etika. Alat ukur yang digunakan adalah dengan menggunakan kuesioner yang diadopsi dari penelitian Jamilah dkk (2007). Konstruk nilai yang digunakan adalah 
5 skala Likert yaitu (1) sangat tidak setuju, (2) tidak sutuju, (3) netral, (4) setuju, dan (5) sangat setuju.

Kompleksitas tugas merupakan persepsi tentang kesulitan suatu tugas yang disebabkan oleh terbatasnya kapabilitas, dan daya ingat serta kemampuan untuk mengintegrasikan masalah yang dimiliki oleh seorang pembuat keputusan (Jamilah dkk, 2007). Alat ukur yang digunakan adalah dengan menggunakan kuesioner yang diadopsi dari penelitian Jamilah dkk (2007). Konstruk nilai yang digunakan adalah 5 skala Likert yaitu (1) sangat salah, (2) salah, (3) netral, (4) benar, dan (5) sangat benar.

Variabel pengalaman audit dilihat dari lamanya bekerja sebagai auditor dan banyaknya penugasan yang pernah ditangani. Alat ukur yang digunakan untuk mengukur variabel pengalaman di sini adalah dengan menggunakan indikator yang dikembangkan oleh Suraida (2003) dalam Susetyo (2009). Pertanyaan yang disampaikan pada kuesioner dikombinasikan untuk pengalaman audit adalah lama bekerja sebagai auditor dan berapa banyak penugasan yang pernah ditangani. Konstruk nilai yang digunakan adalah 5 skala Likert yaitu (1) 0-5 tahun, (2) 6-10 tahun, (3) 11-15 tahun, (4) 16-20 tahun, dan (5) lebih dari 20 tahun. Serta (1) kurang dari 10 penugasan, (2) 11-20 penugasan, (3) 21-30 penugasan, (4) 31-40 penugasan, dan (5) lebih dari 40 penugasan.

Motivasi merupakan penggerak dari dalam hati seseorang untuk melakukan atau mencapai suatu tujuan. Alat ukur yang digunakan adalah kuesioner yang diadopsi dari Giyana (2009). Konstruk nilai yang digunakan adalah 5 skala Likert, yaitu (1) sangat tidak setuju, (2) tidak setuju, (3) netral, (4) setuju, dan (5) sangat setuju.

Audit judgment adalah kebijakan auditor dalam menentukan pendapat mengenai hasil auditnya yang mengacu pada pembentukan suatu gagasan, pendapat, atau pemikiran tentang suatu objek, peristiwa, status, atau jenis peristiwa lain. Alat ukur yang digunakan adalah dengan menggunakan kuesioner yang diadopsi dari penelitian Jamilah dkk (2007). Konstruk nilai yang digunakan adalah 5 skala Likert, yaitu (1) sangat tidak mungkin, (2) tidak mungkin, (3) netral, (4) mungkin, dan (5) sangat mungkin. 


\section{Teknik Analisis Data}

\section{Uji Kualitas Data}

Menurut Sugiyono (2004: 137), sebuah instrumen dikatakan valid jika instrumen tersebut dapat digunakan untuk mengukur apa yang seharusnya diukur. Uji validitas pada penelitian ini menggunakan nilai dalam output Cronbach alpha pada kolom correlated item - total correlation. Menurut Ghozali (2011: 53) suatu butir dapat dianggap valid jika $r$ hitung $>r$ tabel.

Untuk mengukur reliabilitas, uji statistik yang digunakan adalah Cronbach alpha $(\alpha)$. Suatu konstruk nilai dikatakan reliabel jika memberikan nilai Cronbach alpha > 0,70 (Nunnally, 1994 dalam Ghozali, 2011: 48).

\section{Uji Hipotesis}

Metoda statistik yang digunakan adalah dengan menggunakan analysis of covariance (ANCOVA). Pengujian dilakukan dengan menggunakan alat bantu komputer dengan program IBM Statistical Package for Social Sciences (SPSS) versi 19.0.

Model yang digunakan reliabel atau tidak, dapat dilihat pada output Levene's test of equality of homogeneity variances. Jika nilai signifikansi Levene's test kurang dari 0,05, maka model general linier model (GLM) diragukan atau model yang digunakan dalam penelitian kurang reliabel. ANCOVA digunakan untuk mengetahui pengaruh utama (main effect) dan pengaruh interaksi (interaction effect) dari variabel independen terhadap variabel dependen. Hasil pengujian hipotesis 1 , hipotesis 2 , hiotesis 3 , dan hipotesis 4 dapat dilihat main effect-nya melalui nilai signifikansi dalam output test of between-subjects effects. Jika nilai signifikansi masing-masing variabel independen kurang dari 0,05, maka dapat dikatakan bahwa masing-masing variabel independen mempunyai pengaruh terhadap variabel dependen yaitu audit judgment.

Sedangkan untuk mengetahui hasil pengujian dari pengaruh interaksi (interaction effect) (hipotesis 5, hipotesis 6, hipotesis 7, dan hipotesis 8), dapat dilihat pada nilai signifkansi dalam output test of between-subjects effect. Jika nilai signifikansinya kurang dari 0,05, maka dapat dikatakan bahwa gender merupakan variabel moderator. 


\section{HASIL ANALISIS DATA DAN PEMBAHASAN}

Peneliti memperoleh 45 kuesioner yang kembali dari 75 kuesioner yang disebar. Sementara itu, hanya 38 kuesioner yang dapat diolah dan ini berarti ada 7 kuesioner yang tidak dapat diolah.

\section{Uji Kualitas Data}

Jumlah sampel penelitian ini $(\mathrm{n})=38$ dan besarnya degree of freedom $(\mathrm{df})=$ $\mathrm{n}-2$ sehingga besarnya $(\mathrm{df})=38-2=36$. Berdasar $\mathrm{df}=36$ dan alpha=0,05 maka didapat $r$ tabel sebesar 0,320. Jika hasil $r$ hitung lebih besar dari $r$ tabel, maka indikator tersebut dinyatakan valid.

Suatu indikator atau kuesioner dikatakan reliabel jika memberikan nilai Cronbach Alpha $(\alpha)>0,70$ (Nunnally, 1994 dalam Ghozali, 2011: 48).

\section{Uji Hipotesis}

Hasil uji Levene's test menunjukkan nilai signifikansi sebesar 0,651 yang lebih besar dari 0,05. Sehingga dapat diketahui bahwa model yang digunakan dalam penelitian ini adalah reliabel dan syarat untuk menggunakan general linear model (GLM) sudah terpenuhi.

\section{Analisis Pengaruh Tekanan Ketaatan terhadap Audit Judgment (H1)}

Hasil uji ANCOVA, diketahui bahwa tekanan ketaatan tidak berpengaruh terhadap audit judgment. Hal ini ditunjukkan dengan nilai signifikansi sebesar 0,485 > 0,05, maka H1 ditolak. Tekanan ketaatan yang diterima oleh auditor ketika melaksanakan tugas audit tidak berpengaruh secara signifikan terhadap kualitas audit judgment-nya. Hal ini jika auditor menerima perintah yang kurang tepat dari atasan maupun kliennya terkait dengan prosedur pengauditan, mereka berani menentang perintah atasan dan klien walaupun akan ada konsekuensi yang timbul akibat menentang perintah tersebut. Hasil penelitian ini bertentangan dengan penelitian yang dilakukan oleh Jamilah, dkk (2007), Puspitasari (2011), dan Irwanti (2011) yang menyatakan ada pengaruh antara tekanan ketaatan terhadap audit judgment. 


\section{Analisis Pengaruh Kompleksitas Tugas terhadap Audit Judgment (H2)}

Hasil uji ANCOVA, diketahui bahwa kompleksitas tugas berpengaruh terhadap audit judgment. Hal ini ditunjukkan dengan nilai signifikansi sebesar $0,019<0,05$, maka H2 diterima. Hal ini berarti bahwa jika auditor menghadapi tugas yang kompleks akan mempengaruhi kualitas judgment yang dikeluarkannya. Sesuai dengan yang dikemukakan oleh Restuningdiah dan Indriantoro (2000) yang mengatakan bahwa peningkatan kompleksitas dalam suatu tugas atau sistem, akan menurunkan tingkat keberhasilan tugas itu. Hasil penelitian ini konsisten dengan penelitian yang dilakukan oleh Chung dan Monroe (2001) dalam Jamilah, dkk (2007), serta Puspitasari (2011) yang menyatakan bahwa kompleksitas tugas berpengaruh signifikan terhadap audit judgment.

\section{Analisis Pengaruh Pengalaman terhadap Audit Judgment (H3)}

Hasil uji ANCOVA, diketahui bahwa pengalaman tidak berpengaruh terhadap audit judgment. Hal ini ditunjukkan dengan nilai signifkansi sebesar 0,116>0,05, maka H3 ditolak. Ini dikarenakan dalam pemberian opini oleh auditor sudah ada ketentuan yang berlaku dan sikap profesionalisme mereka mendorong mereka untuk menjalankan ketentuan tersebut sehingga jika ditinjau dari segi pengalaman, entah itu auditor baru ataupun auditor lama (berpengalaman) dapat memberikan judgment yang berkualitas selama mereka tidak menyimpang dari ketentuan yang berlaku. Hasil penelitian ini bertentangan dengan penelitian yang dilakukan oleh Zulaikha (2006) yang menyatakan ada pengaruh antara pengalaman terhadap audit judgment. Akan tetapi hasil penelitian ini mendukung penelitian yang dilakukan oleh Susetyo (2009) yang menyatakan bahwa pengalaman audit tidak berpengaruh secara signifikan terhadap audit judgment.

\section{Analisis Pengaruh Motivasi terhadap Audit Judgment (H4)}

Hasil uji ANCOVA menunjukkan bahwa motivasi tidak berpengaruh terhadap audit judgment. Hal ini ditunjukkan dengan dengan tingkat signifkansi sebesar 0,069 > 0,05, maka H4 ditolak. Hal ini dikarenakan motivasi memang dianggap mampu meningkatkan kinerja seseorang, dalam hal ini auditor, akan tetapi seiring dengan meningkatnya kinerja seorang auditor, belum tentu akan 
menghasilkan judgment yang berkualitas atau sesuai dengan keadaan yang sebenarnya. Karena judgment yang berkualitas adalah judgment yang sesuai dengan standar pengauditan yang berlaku umum, bukan berdasarkan pada konflik kepentingan yang ada. Hasil penelitian ini bertentangan dengan hasil penelitian yang dilakukan oleh Suryanti (2010) yang menyatakan bahwa motivasi kerja berpengaruh signifikan terhadap pengambilan keputusan auditor.

\section{Analisis Pengaruh Tekanan Ketaatan terhadap Audit Judgment dengan Gender sebagai Moderator (H5)}

Hasil uji ANCOVA menunjukkan bahwa gender tidak memoderasi pengaruh tekanan ketaatan terhadap audit judgment. Hal ini ditunjukkan dengan nilai signifkansi interaksi gender dengan tekanan ketaatan sebesar 0,940 >0,05, maka H5 ditolak. Hal ini menandakan bahwa antara laki-laki maupun perempuan tidak ada perbedaan dalam hal pertimbangan moral sehingga kualitas judgment yang dikeluarkan oleh auditor laki-laki maupun auditor perempuan ketika sedang memperoleh tekanan entah itu dari klien maupun dari atasan adalah sama. Karena mereka sadar bahwa tugas audit adalah tugas yang membutuhkan profesionalisme yang tinggi. Jika seorang auditor bersikap profesional, maka dia akan tunduk pada etika yang berlaku, baik itu auditor laki-laki maupun perempuan.

\section{Analisis Pengaruh Kompleksitas Tugas terhadap Audit Judgment dengan gender sebagai moderator (H6)}

Hasil uji ANCOVA, diketahui bahwa gender tidak memoderasi pengaruh tekanan ketaatan terhadap audit judgment. Hal ini ditunjukkan dengan nilai signifkansi interaksi gender dengan tekanan ketaatan sebesar 0,454 >0,05, maka H6 ditolak. Ini menunjukkan bahwa peran ganda yang dimiliki oleh auditor perempuan tidak mempengaruhi judgment yang dikeluarkan oleh mereka ketika mereka dihadapkan dengan tugas yang kompleks. Sehingga perbedaan gender tidak perlu dibesar-besarkan karena baik auditor laki-laki maupun auditor perempuan memiliki kemampuan yang sama dalam membuat judgment walaupun perempuan dihadapkan dengan peran ganda. Hasil penelitian ini selaras dengan hasil penelitian yang dilakukan oleh Zulaikha (2006) yang mengatakan bahwa ketika kompleksitas 
tugas berinteraksi (interaction effects) dengan gender, pengaruh interaksi yang dihasilkan tidak signifikan.

\section{Analisis Pengaruh Pengalaman terhadap Audit Judgment dengan gender sebagai moderator $(\mathrm{H7})$}

Hasil uji ANCOVA, diketahui bahwa gender tidak memoderasi pengaruh pengalaman audit terhadap audit judgment. Hal ini ditunjukkan dengan nilai signifkansi interaksi gender dengan pengalaman audit sebesar 0,175 >0,05, maka H7 ditolak. Baik itu auditor laki-laki maupun auditor perempuan memiliki kesempatan yang sama apabila dilihat dari segi nilai, peran, mentalitas, karakteristik emosional, dan tingkah laku. Kesamaan yang ada tersebut akhirnya mereka mempunyai kesempatan yang sama pula untuk mengeluarkan pendapat mereka yang berkualitas, yang sesuai dengan ketentuan yang berlaku. Isu bahwa memori perempuan lebih kuat dibanding memori lakilaki tidak terbukti kebenarannya. Hasil penelitian ini bertentangan dengan hasil penelitian Zulaikha (2006) yang menyatakan bahwa pengalaman dan gender mempunyai interaction effect terhadap audit judgment.

\section{Analisis Pengaruh Motivasi terhadap Audit Judgment dengan gender sebagai moderator (H8)}

Hasil uji ANCOVA, diketahui bahwa gender tidak memoderasi berpengaruh motivasi terhadap audit judgment. Hal ini ditunjukkan dengan nilai signifkansi interaksi gender dengan motivasi audit sebesar 0,254 > 0,05, maka H8 ditolak. Sebab walaupun diduga perempuan lebih condong termotivasi secara intrinsik, dan motivasi intrinsik dianggap menghasilkan dampak yang lebih positif jika dibanding dengan motivasi ekstrinsik, ternyata hal itu tidak berdampak pada judgment yang dikeluarkan oleh auditor perempuan. Apapun jenis motivasi yang mereka miliki, baik itu motivasi intrinsik maupun ekstrinsik, mereka sadar akan tuntutan profesi yang mereka geluti sehingga mereka harus bersikap profesional. Baik auditor lakilaki maupun perempuan jika dihadapkan dengan motivasi yang dimiliki, mereka mampu menghasilkan kualitas judgment yang sama. 


\section{SIMPULAN, KETERBATASAN, DAN SARAN}

Berdasar hasil pengujian maka dapat diperoleh kesimpulan sebagai berikut:

1. Tekanan ketaatan tidak berpengaruh terhadap audit judgment.

2. Kompleksitas tugas berpengaruh terhadap audit judgment.

3. Pengalaman audit tidak berpengaruh terhadap audit judgment.

4. Motivasi tidak berpengaruh terhadap audit judgment.

5. Gender tidak memoderasi pengaruh tekanan ketaatan terhadap audit judgment.

6. Gender tidak memoderasi pengaruh kompleksitas tugas terhadap audit judgment.

7. Gender tidak memoderasi pengaruh pengalaman terhadap audit judgment.

8. Gender tidak memoderasi pengaruh motivasi terhadap audit judgment..

Penelitian ini memiliki keterbatasan-keterbatasan sebagai berikut:

1. Waktu yang relatif lama dan sedikitnya responden dalam penelitian ini, yaitu bulan Agustus sampai bulan Oktober 2012. Hal ini karena pada bulan tersebut auditor sedang sibuk sehingga hanya sedikit kantor akuntan publik dan auditor yang mempunyai waktu untuk menerima penelitian.

2. Penelitian ini dilakukan di DIY dan Semarang dan ternyata hanya sedikit kuesioner yang kembali.

3. Variabel dalam penelitian ini adalah tekanan ketaatan, kompleksitas tugas, pengalaman, dan motivasi yang mempengaruhi kualitas audit judgment dan variabel gender digunakan sebagai variabel moderator. Akan tetapi dari variabel yang ada, hanya satu variabel yang berpengaruh.

Setelah didapatkan hasil dalam penelitian ini, maka peneliti memberikan beberapa saran yang dapat bermanfaat bagi penelitian selanjutnya. Saran yang peneliti berikan untuk penelitian berikutnya adalah:

1. Memilih waktu yang tepat dalam melakukan penelitian, misalnya pada bulan April sampai Juli karena pada waktu tersebut kemungkinan auditor tidak terlalu sibuk dan ada waktu untuk menerima penelitian/ kuesioner.

2. Memperluas lingkup penelitian sehingga sampel yang terkumpul cukup banyak dan mampu memperoleh hasil yang lebih baik.

3. Mampu mengembangkan penelitian yang telah dilakukan, yaitu dengan meneliti variabel lain yang diduga mampu mempengaruhi kualitas audit judgment yang 
diberikan oleh auditor seperti variabel skeptisme profesional auditor, serta selfefficacy.

\section{DAFTAR PUSTAKA}

Andini, Prita. 2010. "Pengaruh Evaluasi Etis, Orientasi Etis, dan Intensi Etis terhadap Kinerja Auditor dari Sudut Pandang Gender dan Psikologi Humanistik Sebagai Disiplin Ilmu". Budi Luhur Economics Journal vol.5 no.1.

Arikunto, Suharsimi. 1995. Manajemen Penelitian. Yogyakarta: Rineka Cipta.

Bakat berawal dari kemampuan, 23 November 2010, [Online] Didapatkan: http://www.suaramerdeka.com [26 Juni 2012].

Bawono, Icuk Rangga, Elisha Muliyani Singgih. 2010. "Faktor-faktor dalam Diri Auditor dan Kualitas Audit". Jurnal Akuntansi dan Auditing Indonesia vol.14 no.2.

Boynton, William C., Raymond N. Johnson, Walter G. Kell. 2003. Modern Auditing. Jakarta: Erlangga.

Departemen Pendidikan Nasional. 2011. Kamus Besar Bahasa Indonesia. Jakarta: Gramedia Pustaka Utama.

Echols, John M., Hassan Sadhily. 1983. Kamus Inggris-Indonesia. Jakarta: Gramedia Pustaka Utama.

Engko, Cecilia \& Gudono. 2007. "Pengaruh Kompleksitas Tugas dan Locus of Control terhadap Hubungan antara Gaya Kepemimpinan dan Kepuasan Kerja Auditor". Jurnal Akuntansi dan Auditing Indonesia vol.11 no.2.

Giyana. 2009. Analisis Pengaruh Reward dan Kepemimpinan terhadap Motivasi Kerja Karyawan PT. Sari Husada. Skripsi. Yogyakarta: Universitas Ahmad Dahlan.

Hamalik, Oemar. 2000. Psikologi Belajar dan Mengajar. Bandung: Sinar Baru Algessindo.

Hartanto, Hansiadi Yuli \& Indra Wijaya Kusuma. 2001. "Analisis Pengaruh Tekanan Ketaatan terhadap Judgment Auditor". Jurnal Akuntansi dan Manajemen STIE YKPN vol. 12 no. 3 hal. 5-18 (Desember). 
Herliansyah, Yudhi \& Meifida Ilyas. 2006. "Pengaruh Pengalaman Auditor terhadap Penggunaan Bukti Tidak Relevan dalam Audit Judgment". Simposium Nasional Akuntansi IX.

Irawanti, Ajeng Nurdiyani. 2011. Pengaruh Gender Tekanan dan Ketaatan terhadap Audit Judgment, Kompleksitas Tugas Sebagai Variabel Moderating. Skripsi. Semarang: Universitas Diponegoro.

Ittonem, Kim \& Emillia Peni. 2012. “Auditor's Gender and Audit Fee's". International Journal of Auditing vol. 16 hal: 1-18.

Jamilah, Siti, Zaenal Fanani, dan Grahita Chandrarin. 2007. "Pengaruh Gender, Tekanan Ketaatan, dan Kompleksitas Tugas terhadap Audit Judgment" Simposium Nasional Akuntansi X.

Jardon, Ruth Chatelain, Jesus Carmona, Ned Kock, Alicia Cavazos Garza, dan Vanessa Garza. 2007. "The Effect of Gender on Performance in a WebBased Knowledge Communication Task”. IRMA International Converence.

Kartono, Kartini. 2002. Psikologi Sosial untuk Manajemen Perusahaan dan Industri. Jakarta: PT. Raja Grafindo Persada.

Keraf, Sonny. 2004. Etika Bisnis Tuntutan dan Relevansinya. Yogyakarta: Kanisius.

King, Laura A. 2010. Psikologi Umum. Jakarta: Penerbit Salemba Humanika. (diterjemahkan oleh: Brian Marwensdy)

Koroy, Tri Ramaraya. 2005. "Pengaruh preferensi Klien dan Pengalaman Audit terhadap Pertimbangan Auditor". Simposium nasional Akuntansi VIII.

Mangkunegara, A.A. Anwar Prabu. 2005. Manajemen Sumberdaya Manusia Perusahaan. Bandung: Remaja Rosdakarya.

Mulyadi. 2002. Auditing. Yogyakarta: Salemba Empat.

Nadhiroh, Siti Asih. 2010. Pengaruh Kompleksitas Tugas, Orientasi Tujuan, dan Self-Efficacy terhadap Kinerja Auditor dalam Pembuatan Audit Judgment. Skripsi. Semarang: Universitas Diponegoro. 
Nasution, Damai. 2008. "Senjangan Gender terhadap Motivasi dan Self-Efficacy pada Keberterimaan Teknologi Informasi”. Jurnal Organisasi dan Manajemen vol.4 no.1 (Maret).

Riduwan. 2008. Belajar Mudah Penelitian untuk Guru, Karyawan, dan Peneliti Pemula. Bandung: Alfabeta.

Restuningdiah, Nurika \& Nur Indriantoro. 1999. "Pengaruh Partisipasi terhadap Kepuasan Pemakai dalam Pengembangan Sistem Informasi dengan Kompleksitas Tugas, Kompleksitas Sistem, dan Pengaruh Pemakai sebagai Variabel Moderating". Simposium Nasional Akuntansi II.

Sabaruddinsah. 2007. "Pengaruh Gender, Pengalaman Auditor, dan Kompleksitas Tugas terhadap Audit Judgment".

Sardiman, A. M. 1988. Interaksi dan Motivasi Belajar Mengajar. Jakarta: Rajawali Pers.

Stoller, Robert J., 1968, Sex and Gender: On the Development of Masculinity and Femininity [Online] Didapatkan: http://www.books.google.co.id [5 Agustus 2012].

Sugiyono. 2003. Metode Penelitian Administrasi. Bandung: Alfabeta.

Suryanti, Endang. 2010. "Pengaruh Motivasi Kerja dan Etika Profesi terhadap Pengambilan Keputusan Auditor". Probank vol.18 no.8 (Januari).

Susetyo, Budi. 2009. Pengaruh Pengalaman Audit terhadap Pertimbangan Auditor dengan Kredibilitas Klien Sebagai Variabel Moderating. Tesis. Semarang: Universitas Diponegoro.

Trisnaningsih, Sri. 2004. "Perbedaan Kinerja Auditor Dilihat dari Segi Gender". Jurnal Riset Akuntansi Indonesia vol. 7 no. 1 hal 108-123 (Januari).

Tyson, Shaun \& Tony Jackson. 1992. Perilaku Organisasi. Yogyakarta: Andi. (diterjemahkan oleh Deddy Jacobus \& Dwi Prabantini).

Wade, Carole \& Carol Tavris. 2007. Psikologi. Jakarta: Penerbit Erlangga. (deterjemahkan oleh: Benedictine Widyasinta \& Ign. Darma Juwono).

Winkel, W. S. 1996. Psikologi Pengajaran. Jakarta: Grasindo. 
Yuliawan, Kadek Oka. 2009. Perbedaan Gender dalam Penggunaan Gaya Kepemimpinan Transformasional dalam suatu Pengujian Diri Perspektif Atasan, Bawahan, dan Diri Sendiri Studi pada Perguruan Tinggi Swasta di Daerah Istimewa Yogyakarta. Skripsi. Yogyakarta: Universitas Ahmad Dahlan.

Zulaikha. 2006. "Pengaruh Interaksi Gender, Kompleksitas Tugas, dan Pengalaman Auditor Terhadap Audit Judgment" Simposium Nasional Akuntansi IX. 